\title{
Study of The Biological Effects of the Aqueous Extract of the Flower of Target Taraxacum Officinale on Escherichia Coli Ab1157
}

\author{
Faria TC ${ }^{1}$, Nascimento CCHC ${ }^{1}$, Vasconcelos De SDD ${ }^{1,3}$, Stephens PRS ${ }^{4}$, Saranraj $\mathrm{P}^{5}$, Barreto $\mathrm{AS}^{1}$ and Diré GF $\mathrm{G}^{1,2 *}$ \\ ${ }^{1}$ Laboratory of Chemical and Biological Analysis (LAQB), Foundation State University Center of the West Zone (UEZO), Brazil \\ ${ }^{2}$ Estácio de Sá University (UNESA), Brazil
}

${ }^{3}$ Federal Center of Technological Education Celso Suckow da Fonseca-CEFET-NI, Brazil

${ }^{4}$ Laboratory of Innovations in Therapies, Oswaldo Cruz Institute, Brazil

${ }^{5}$ Department of Microbiology, Sacred Heart College (Autonomous), India

Submission: September 04, 2019; Published: October 04, 2019

*Corresponding author: Diré GF, Laboratory of Chemical and Biological Analysis (LAQB), Foundation State University Center of the West Zone (UEZO), Avenue Manuel Caldeira de Alvarenga, 1203, Campo Grande, Estácio de Sá University (UNESA), Rio de Janeiro, 23070-200, BrazilPublic Health, Southeast University, Nanjing, 210009, Jiangsu Province, China Taha Hussein Musa, Key Laboratory of Environmental Medicine Engineering, Ministry of Education. Department Epidemiology and Health Statistics, School of Public Health, Southeast University, Nanjing, 210009, Jiangsu Province, China \& Biomedical Research Institute, Darfur College, Nyala, Sudan

\begin{abstract}
The present study shows the results obtained by the disc-diffusion test, where the actions of the aqueous extract of the flower of Taraxacum officinale on the strain Escherichia coli AB1157 was evaluated and compared with the results of the aqueous extract of Schinus terebinthifolius Raddi. It can be observed that the extract of Taraxacum officinale presented greater significance in relation to inhibition of bacterial growth than the extract of Schinus terebinthifolius Raddi, suggesting to the extract of Taraxacum officinale a greater and better clinical relevance.
\end{abstract}

Keywords: Taraxacum officinale; Schinus terebinthifolius raddi; Escherichia coli; Disc diffusion clinic

\section{Introduction}

Due to the great development of societies, plants have become an important therapeutic medium through man, since they have immeasurable biologically operative substances which allow the synthesis of countless other synthetic substances for the analysis of the diverse diseases that affect humans [1,2]. According to the progress of technology and the recent notions of sustainability that became common practice from the twentieth century, the use of plant herbal forms has increased worldwide, especially in Brazil, due to its gigantic vegetal biodiversity, which stimulates new studies in order to create new drugs that meet the therapeutic needs and are safe for human health, as well as for all biological areas $[1,3]$.

Aiming at this aspect, some plant forms of the genus Taraxacum, popularly known as Dandelion, have long been applied in medicine and known to supplant hepatic disorders, breast cancer and uterus, acting as diuretics, choleretic, anti-inflammatory $[4,5]$.
From the Asteraceae family, of which the plant species Taraxacum officinale, popularly known as dandelion, has a global distribution, is better expressed in the temperate and subtropical regions, in approximately 1,100 genera and 19,000 species [6].

Among the various substances are secondary metabolites, essential oils, tannins, oil-resins, terpenes, flavonoids, saponins, organic acids, and other chemical complexes $[7,8]$ which are evidenced by their chemical effect, since they can be used for immeasurable related research, since they present diverse properties as anti-inflammatory, antioxidants, anticancer, antimicrobial and several others that contribute to the investigation [9].

Among the substances extracted from Taraxacum officinale are the terpene derivatives taraxerol, taraxasterol and the glycoside taraxacoside [10], in addition to sterols ( $ß$-sitosterol, stigmasterol), rubber, resins, indices of essences, fatty bodies, levulose, a galactose polyholoside and arabinose, caffeic acid, p-hydroxyphenyl acetic acid, asparagine, tyrosine 15 , choline, levunin and pectin 
[11], tannins, carotenoids, phytosterol [12], ß-amirin, flavonoids, citric acid, amino acids, saponins and inulin [10]. In the view of [13] the roots contain from $25 \%$ to $38 \%$ of inulin (Figure 1), resin and triterpenic derivatives, responsible for the amargol flavor, and sesquiterpene lactones, represented by taraxacin.

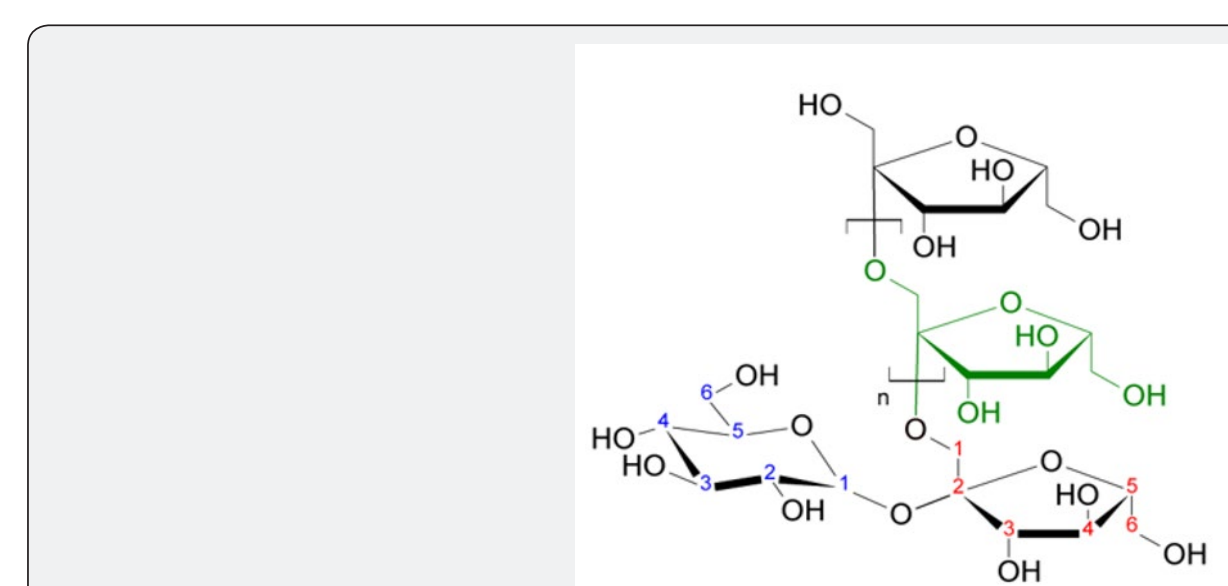

Figure 1: Chemical structure of Inulin (substance responsible for major pharmacological (Effects).

The aqueous extract of Taraxacum officinale has been elucidated by having strong anti-tumor promotion activities in the twostage carcinogenesis of mouse skin tumor induced by an initiator and a promoter. In addition, this extract also has antiangiogenic, anti-inflammatory and antinociceptive activities, that is, capable of minimizing the production of nitric oxide (NO) and cyclooxygenase 2 (COX-2) and decrease the rate of reactive oxygen species (ROS) in cells activated macrophages [14].

This species is vast in minerals such as iron, copper and potassium, and contains vitamins B1, PP and D $[10,15]$ and contains many more vitamins $\mathrm{A}(14,000 \mathrm{IU} / 100 \mathrm{~g})$ and C part of the vegetables [11,13]. Its accumulation in zinc gives it anti-free radical action, being able to protect liver cells from indirect problems, and its high potassium content ensures a better balance of spoliation through the urine. When used in rat experiments, it showed moderate anti-inflammatory action, decreasing pain access and rheumatic disruption. Experimental evidence indicates that $\mathrm{Ta}$ raxacum officinale modulates the glycemic rate. This finding is probably in part as a result of the high content of inulin contained in the plant. Inulin is a polysaccharide fiber composed of extensive sequences of fructose molecules, so it works by preventing variations in blood sugar parameters and reducing the rate of glucose [10]. In addition to the diuretic properties, the species presents slightly laxative properties, stimulating the release of gastric juice, as well as choleretic, collagenous, depurative, antirheumatic and antiscorbic activity, being able to be applied against constipation, facial skin diseases (pruritus, eczemas, scaling and redness), acidosis, headache, jaundice and uric acid disorders [10-12,16]. Taraxacum officinale is commonly found in many pharmacopoeias, such as Switzerland, Hungarian, Russian, Polish, Austrian, Chinese and British, as well as being considered as a natural flavoring and can be inserted into foodstuffs in small portions $[13,17]$. The adverse or complex toxic effects for T. officinale have not yet been mentioned when consumed in common portions or as foods. However, it is worth noting that mild hypotension has been reported due to the diuretic effect, as well as contact dermatitis in individuals hypersensitive to sesquiterpene lactones (Figure 2) of the latex [13].

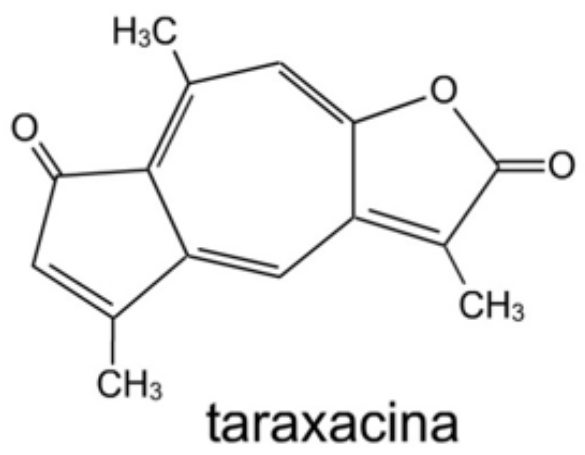

Figure 2: Sesquiterpene lactone presents in the species Taraxacum officinale. 
As mentioned, this species possesses immeasurable properties that make it a source of study for countless studies, among which the microbiological character of bacterial studies with the use of Escherichia coli strains, especially the species of the genus Escherichia, the wild strains AB 1157 that are In the present work, the exonuclease III is used in the repair of DNA oxidative lesions in an exponential phase of development [18], both of which are effective in all DNA repair genes and BW 9091, mutant of the xthA gene employed in this study.

\section{Materials and Methods}

\section{Plant obtainment}

The botanical material containing the part of the flowers of $T a$ raxacum officinale was obtained from the market in Madureira, in the Northern Zone of the municipality and state of Rio de Janeiro. This material was transported to the Laboratory of Chemical and Biological Analysis (LAQB) located at the State University Center of the West Zone (UEZO) located in Campo Grande in a plastic container at room temperature.

\section{Preparation of aqueous extract}

The sample obtained from the flower of Taraxacum officinale was duly sanitized with distilled water, trimmed with scissors to match a size of approximately $1 \mathrm{~cm}^{2}$, weighed in a semi-analytical scale the amount of 500 grams and infused with $1000 \mathrm{~mL}$ of distilled water heated to $80^{\circ} \mathrm{C}$ in a polyethylene tray for 60 minutes. The extract was sieved, and gravity filtered on filter paper in order to remove the coarse particles of disinterest. They were fractionated in amber glasses with volumetric capacity of $10 \mathrm{ml}$, in order to facilitate the use in the experiments. After cooling, the extract was allocated at a constant temperature of $-20^{\circ} \mathrm{C}$ in a freezer for plasma. The final concentration of the extract was $50 \mathrm{mg} / \mathrm{mL}$.

\section{Preparation of the culture medium for the antimicrobial sensitivity assay (Disk-Diffusion)}

In order to prepare the culture medium, initially, $28 \mathrm{~g}$ of dehydrated medium of Nutrient Agar was weighed and 1 liter of distilled and homogenized water was added for complete dissolution of the product. The prepared solution was then autoclaved at $12^{\circ} \mathrm{C}$ for 15 minutes at a pressure of $101325 \mathrm{~Pa}(1 \mathrm{~atm})$. In a safety booth, $50 \mathrm{ml}$ of the culture medium was poured into $150 \mathrm{~mm}$ glass Petri dishes with the aid of a volumetric pipette and cooled to room temperature until solidified. The plates were packed with clear flexible PVC films and stored in the refrigerator at $5^{\circ} \mathrm{C}$ until used in the experiments.

\section{Reactivation of Escherichia coli strain AB1157}

For the activation of the bacterial strain, with a $10 \mu \mathrm{L}$ disposable bacterial loop, a sample of E. coli AB1157 bacteria was taken from the refrigerated stock (15\% Glycerol in TSB Broth - Soy Tryptone), placed in a tube containing $3 \mathrm{~mL}$ of Tryptone Soy Broth. The tubes were sealed, homogenized and incubated in a bacteriological oven at $37^{\circ} \mathrm{C}$ for 24 hours. After incubation period, the activated material was seeded in a $90 \mathrm{~mm}$ Petri dish containing Nutrient Agar with the aid of a $10 \mu \mathrm{L}$ bacteriological loop and incubated again. After the 24 hour period inside the biological safety booth, $10 \mu \mathrm{L}$ of the colony forming unit sample (CFU) was collected with the aid of a disposable bacteriological loop and filled into capped test tubes containing $5 \mathrm{ml}$ of $\mathrm{NaCl}$ to $0.9 \%$ ) until reaching the turbidity standard of the McFarland scale, whose index corresponds to $1.5 \times 108 \mathrm{CFUm}^{-1}$, allowing the adequate dilution level for sowing by exhaustion in $150 \mathrm{~mm}$ Petri dishes with the aid of swabs disposables.

\section{Bacterial strain evaluated}

To perform the experiments, the bacterial strain of Escherichia coli: AB 1157, wild type, was tested with all efficient DNA repair mechanisms [18].

\section{Antimicrobial sensitivity test (Disco-Diffusion)}

To evaluate the sensitivity of bacterial strains to the action of extracts, the antimicrobial susceptibility test was performed, which corresponds to the method most used in the microbiology laboratory, since it allows the analysis of the susceptibility of microorganisms against different antimicrobial agents, in a fast and safe way [19].

In the conduction of the dehydrated aqueous extract experiment, the strain Escherichia coli AB1157, previously activated as previously described was used. In the experiment, $18-150 \mathrm{~mm}$ Petri dishes containing $50 \mathrm{~mL}$ Nutrient Agar medium were prepared in 6 groups, all in triplicates. To each plate were added five discs, except those of the last group, in which only 3 discs were positioned, making a total of 26 discs. Disks containing the antibiotics Chloramphenicol, Cephalexin and Ampicillin associated with Sulbactam were purchased from Oxoid Brasil Ltda. and have determined concentrations, in the order of: $30 \mu \mathrm{g} \cdot \mathrm{mL}^{-1}$ for Chloramphenicol-impregnated Disks; $30 \mu \mathrm{g} \cdot \mathrm{mL}^{-1}$ for Cephalexin; $20 \mu \mathrm{g} \cdot \mathrm{mL}^{-1}$ for disks containing Ampicillin associated with Sulbactam.

The discs impregnated with Amoxicillin were previously prepared in the LAQB, from tablets of the Neo-chemical laboratory in the concentration of $250 \mathrm{mg}$. $5 \mathrm{~mL}^{-1}$. The solution was prepared from the dissolution of one tablet in $1 \mathrm{ml}$ of distilled water. After these procedures, the $150 \mathrm{~mm}$ Petri dishes were removed from the refrigerator, placed on the stand for 30 minutes until they reached room temperature and the excess moisture was absorbed, so they were marked with marker pen, arranged in each group, with the discs properly numbered and dated. After this interval, in a biological safety booth, with the aid of sterile swabs, the previously activated Escherichia coli strain AB1157 was inoculated in striatum format on the Agar surface in three directions, thus allowing complete depletion of the surface of the agar medium culture. After this step, the sterile paper discs were applied with sterile forceps to prevent contamination. All discs were gently pressed allowing contact with the surface of the Agar. The distances of $30 \mathrm{~mm}$ between a disc and $15 \mathrm{~mm}$ from the edge of the plate were 
maintained, preventing the overlap of inhibition halos [19]. At the end of sowing, the plates were stored in a bacteriological oven for 24 hours at $35^{\circ} \mathrm{C}$. When reading the results, a halo measurement rule was used in antibiogram.

\section{Statistical analysis}

The results were analyzed with the help of the GraphPad software (GraphPad Software, Inc., USA) from the Variance Analysis (ANOVA) tests. The arithmetic averages were compared to evaluate the proportionality between volume, treatments when associated with the aqueous extract of T. officinale and the diameter of the inhibition halo. The Tukey Kramer test compared the arithmetic mean of the inhibition halos of the different treatments, establishing the significance for $\mathrm{p}<0.05$.

\section{Results}

\section{Therapeutic activity}

The following graphs and tables present the results obtained in the disk-diffusion test for the strain Escherichia coli AB1157, as well as the treatment with the aqueous extract of Taraxacum officinale, in which the formation of halos of inhibition of the bacterial growth against the respective strain. According to the analysis of variances (ANOVA) of the results for the test of antibacterial activity, a value of $p$ lower than 0,0001 , considered extremely significant, is observed. The Tukey-Kramer multiple comparison test had a q value greater than 4,956 , so $\mathrm{p}$ is less than 0.05 (Figure 3 \& 4).

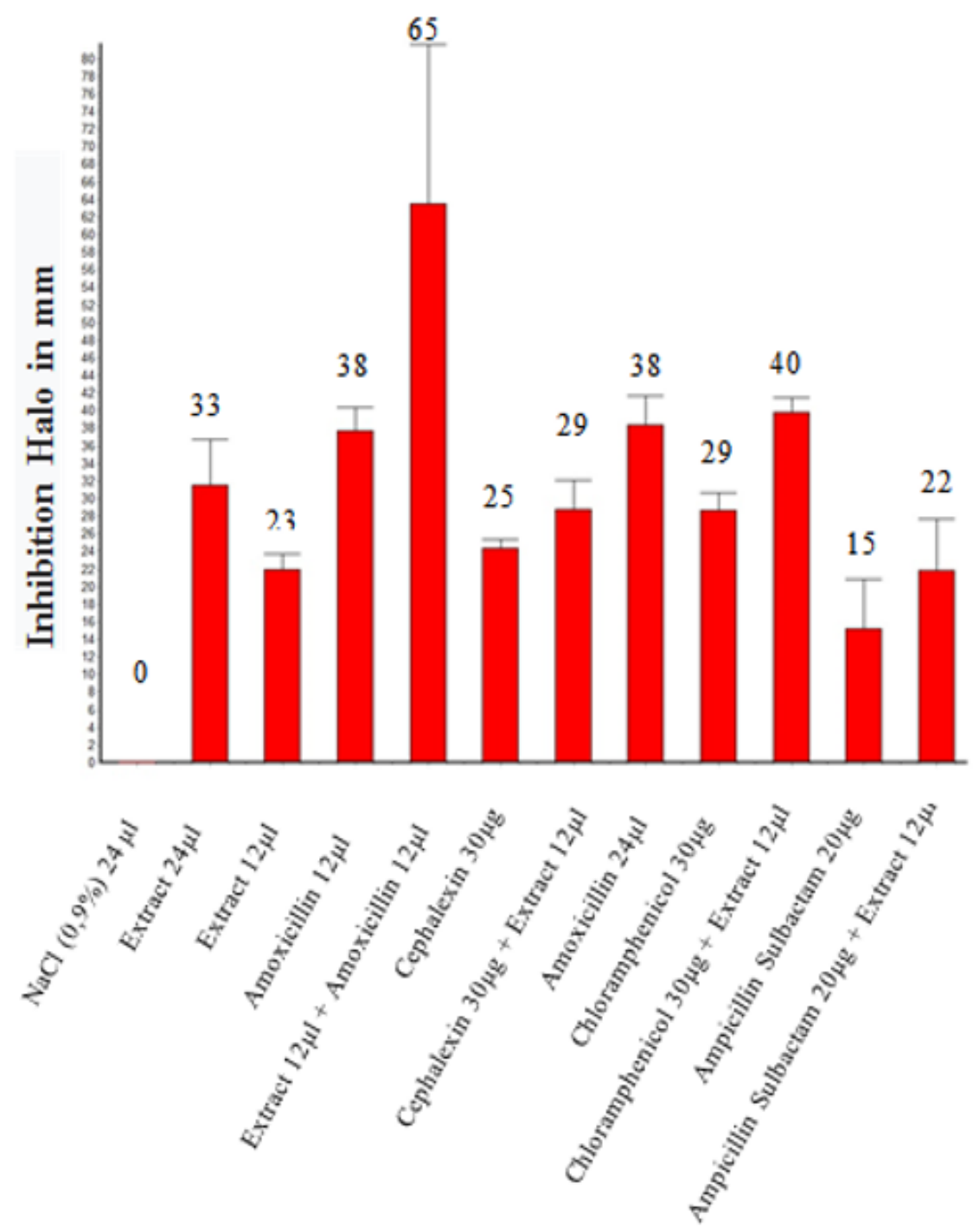

Contents of the Discs

Figure 3: Correlation of the various treatments using different volumes, associated or not to the aqueous extract of the Taraxacum officinale flower and the bacterial growth inhibition halos for strain $A B 1157$. 
Figure 4: Correlation of the various treatments using different volumes, associated or not to the aqueous extract of Schinus terebinthifolius Raddi flower and the bacterial growth inhibition halos for strain AB 1157.

\section{Antioxidant correlation}

The following graphs present the results obtained in the disc-diffusion test with the antioxidant agent known in the literature for the bacterial strain investigated (Escherichia coli AB1157), as well as its respective concentration and the aqueous extracts, in which there was formation of inhibition halos of the bacterial growth against the respective strain (Figure $5 \& 6$ ).

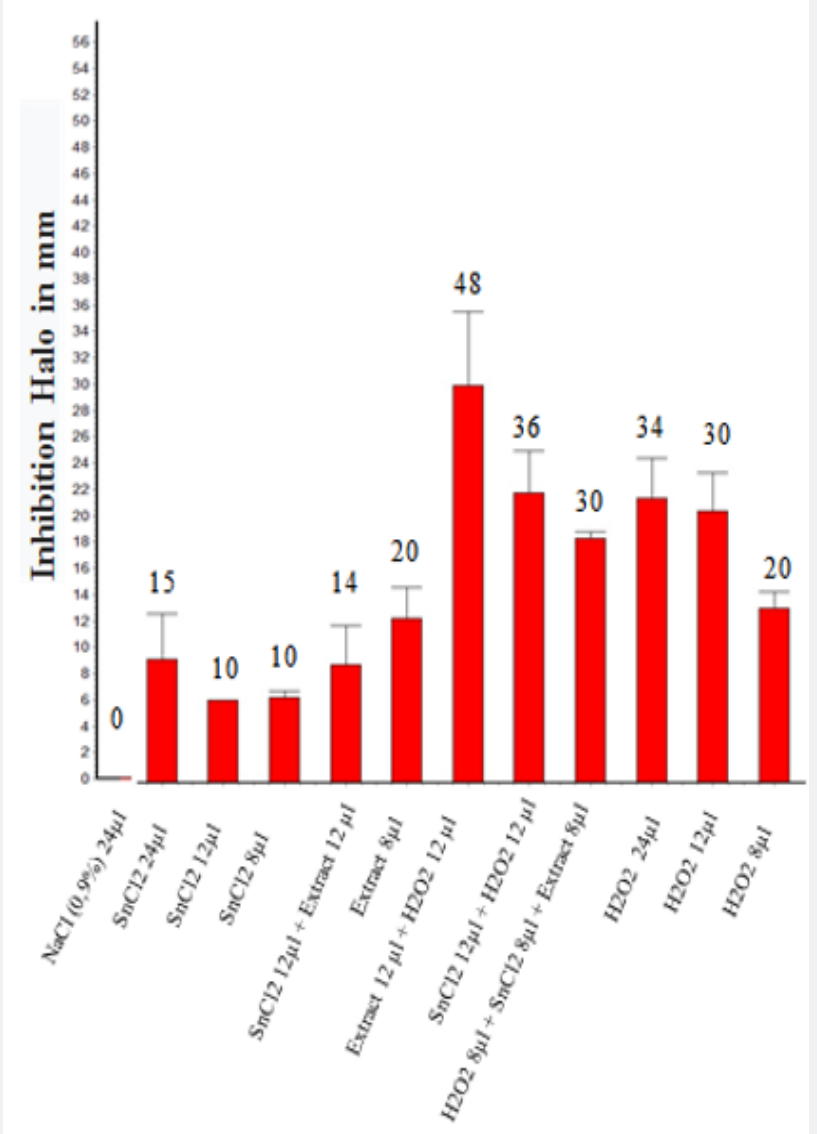

\section{Contents of the Discs}

Figure 5: Correlation of the various treatments using different volumes, associated or not to the aqueous extract of the Taraxacum officinale flower and the bacterial growth inhibition halos for strain $A B 1157$. 


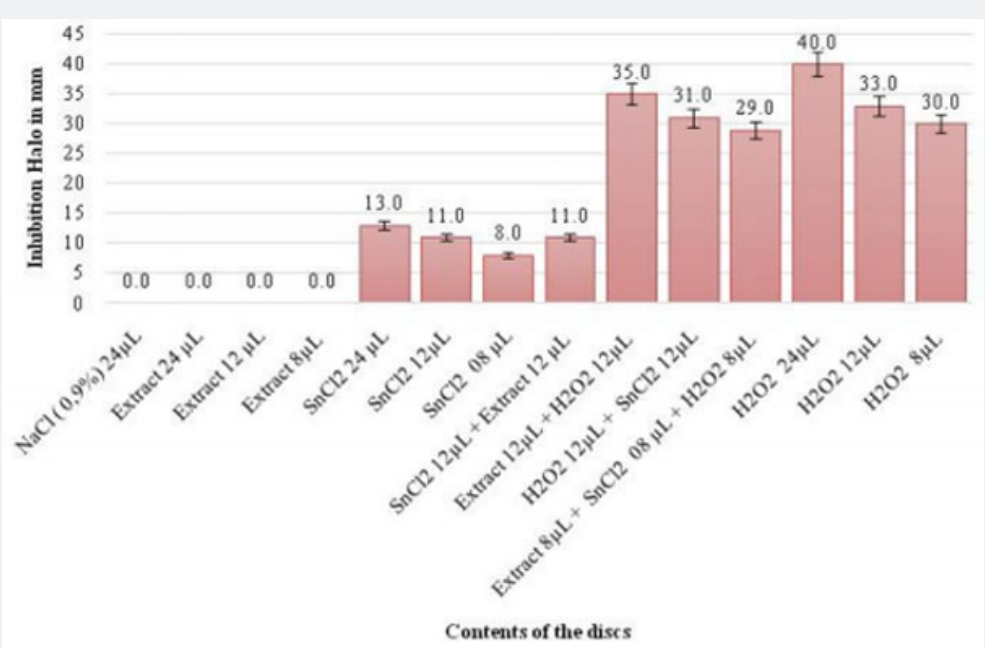

Figure 6: Correlation of the various treatments using different volumes, associated or not to the aqueous extract of Schinus terebinthifolius Raddi and the bacterial growth inhibition halos for strain AB 1157.

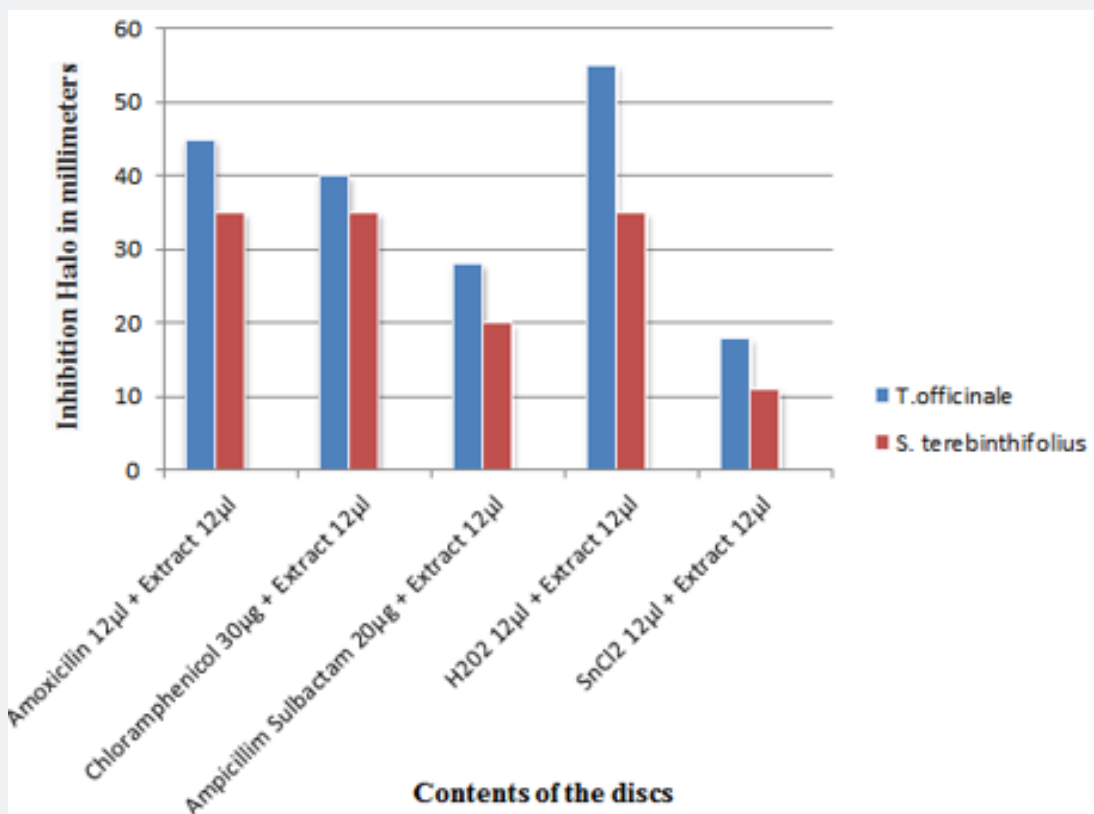

Figure 6: Comparison of averages of the halos formed by the species Taraxacum officinale and Schinus terebinthifolius Raddi on the strain of Escherichia coli AB1157.

Table 1: Comparisons of the halos formed with isolated antibiotics and antioxidants and the respective associations to the aqueous extract of the flower of Taraxacum officinale on the strain of Escherichia coli AB1157.

\begin{tabular}{|c|c|c|}
\hline Comparisons & Difference of Halos in mm & Tukey-Kramer (P) \\
\hline $\begin{array}{c}\text { Amoxicillin } 12 \mu \mathrm{l}+\text { Extract } 12 \mu \mathrm{l} \\
\text { Amoxicillin } 12 \mu \mathrm{l}\end{array}$ & 27 & $\mathrm{P}<0.001$ \\
\hline $\begin{array}{c}\text { Cephalexin } 30 \mu \mathrm{l}+\text { Extract } 12 \mu \mathrm{l} \\
\text { Cephalexin } 30 \mu \mathrm{l}\end{array}$ & 4 & $\mathrm{P}>0.05$ \\
\hline $\begin{array}{c}\text { Chloramphenicol } 30 \mu \mathrm{l}+\text { Extract } 12 \mu \mathrm{l} \\
\text { Chloramphenicol } 30 \mu \mathrm{l}\end{array}$ & 11 & $\mathrm{P}<0.001$ \\
\hline $\begin{array}{c}\text { Ampicillin } 20 \mu \mathrm{l}+\text { Extract } 12 \mu \mathrm{l} \\
\text { Ampicillin } 20 \mu \mathrm{l}\end{array}$ & 6 & $\mathrm{P}>0.05$ \\
\hline
\end{tabular}




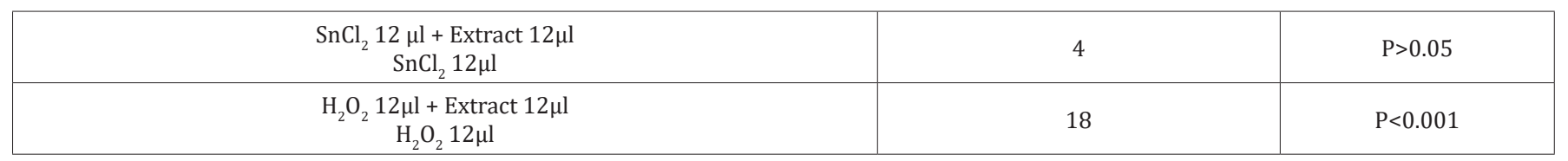

\section{Comparative analysis}

Aqueous extracts from the flower of the species Taraxacum officinale were tested against the bacterial culture of Escherichia coli AB1157 by Agar diffusion method. The results obtained were duly compared with the results of the aqueous extract of the branches and leaves of the species Schinus terebinthifolius Raddi, which was also tested by the disc-diffusion method (Table 1 \& Figure 7).

\section{Discussion}

\section{Therapeutic activity}

Aqueous extracts from the flower of the species Taraxacum officinale, popularly known as Dandelion, were tested against the wild-type bacterial strain Escherichia coli AB1157 by agar diffusion method. According to literary studies, several secondary metabolites that constitute this species, such as saponins, inulins, terpene derivatives, taraxacosides glycosides, sterols and among other substances, are elucidated as the possible responsible for the action both antibacterial, as well as in the aid of the fight against inflammation and reduction of the non-metastatic tumor, which are the three highlights of this study.

In relation to Escherichia coli AB1157, which was treated with the aqueous extract of the Taraxacum officinale flower, a very significant formation of bacterial growth inhibition halos was observed, and this result may be related to the considerations of that describes this bacterium as being proficient in all DNA repair genes, establishing a possible antibacterial action of the extract because it presents the constituents mentioned above, acting on the oxidative lesions in exponential phase of growth [18].

Figure 3 shows the correlation of several treatments using different volumes, associated or not to the aqueous extract of the flower of the species Taraxacum officinale according to the growth halo formation. The diameter of the halo formed by bacterial growth is inversely proportional to the minimum inhibitory concentration (MIC), so the larger the diameter of the halo, the greater the action of the substance used. Thus, it was observed that when the aqueous extract of the flower was used in both $24 \mu \mathrm{L}$ and $12 \mu \mathrm{L}$ and $8 \mu \mathrm{L}$ concentrations, there was a reduction in the growth of the wild strain (E.coli AB1157), but this inhibition was not as significant as when combined with the antibiotic Amoxicillin, both in concentrations of $12 \mu \mathrm{L}$, generating an inhibition halo with a mean diameter of $65 \mathrm{~mm}$.

This same inhibition line was observed for the antibiotics Cephalexin, Chloramphenicol and Ampicillin (Figure 3), because when it was associated with the aqueous extract of the flower a larger diameter was obtained than when administered the antibiotic alone. Thus, it can be suggested that the aqueous extract of the Taraxacum officinale flower acts as a potentiate of antibiotics and may also decrease bacterial resistance, especially of the strain Escherichia coli AB1157, to the antibiotics tested, giving a greater emphasis to the antibiotic Amoxicillin.

These results corroborate those that were found by Silva et al. [20], who in recent research observed that the aqueous extract of the species Schinus terebinthifolius Raddi also acted to inhibit the bacterial growth of this same wild strain, thus confirming an effective action of phytotherapics on the antibacterial effect.

In relation to the results obtained, linked to the halo increase, there is a synergic action, ie a possible drug interaction occurs between the phytocomplexes of the natural extract and the main functional groups of the antibiotics tested. Some of the best literary classics cite that derived from the secondary metabolism of Taraxacum officinale, interfere with the mechanism of action of antibiotics, resulting in potentiation of their pharmacological activities [21].

Phytotherapeutic molecules can interact with these compounds, resulting in negative activities in the bacterial organism, which could justify the formation of inhibition halos in the strain E. coli AB1157 that was treated with the aqueous extract, since the extract is composed of complex mixtures of several chemical heterocytes that may be responsible for various actions, such as antagonistic or synergistic effects of drugs, as a result of the interaction of several active chemical constituents [22]. However, on many occasions the constituent chemicals responsible for the pharmacological activities of medicinal plants may increase the possibility of interactions when the drugs are used concomitantly [23].

According to Nascimento et al. [24], plant by-products can prevent, increase or even exert no effect on the medicinal effect of certain conventional compounds present in medicinal products. In a review of the literature, they verified that phytotherapy may interfere with the pharmacokinetics and/or pharmacodynamics of several drugs. To determine the existence of interactions and interferences in the combination of two aqueous extracts of $\mathrm{Pu}$ nicagranatum and Plantago major in strains of E. coli, concluded that there is interaction between the extracts and the antibiotic tested, amoxicillin, this interaction may occur in the same way with other antibiotics associated with other extracts from other plants $[21,25]$.

These interactions may be related to the fact that antibiotics have many functional hydroxyl groups $(-\mathrm{OH})$, a polar radical, which allows hydrocarbons, even non-polar, to interact well with phytocomplexes, which in many molecular arrangements also have numerous polar radicals. Thus, these hydrocarbons form heterogeneous systems with water. Moreover, in all cases, the polarity of the molecule depends on several chemical factors, as well as the 
arrangement of atoms and the presence of non-binding electrons. Many of these compounds having a - $\mathrm{OH}$ functional group attached to saturated carbon atoms are soluble in polar solvents because of the association of the hydrogen bonds. Thus, while many secondary plant metabolites are formed by phenolic compounds, the drug interaction may be present since phenols also have the $-\mathrm{OH}$ group attached to a carbon atom of an aromatic ring, thus forming a hydrogen bond with water and increasing its solubility. In this way, the various organic functions give rise to a vast set of complex molecules whose solubility and interaction are directly associated with their chemical structures. In this way, several biological processes are directly related to the solubility of the organic substances, and with the possibility of formation of the hydrogen bonds, which make them highly soluble in the aqueous phase [26].

The type of aqueous extract used in the present study is in agreement with Santos et al. [27], where they affirm that there is no systematization that allows a correlation between the parts of the plant used and the type of extract tested with the antimicrobial property, since the substances present in the different parts of the vegetal tissues, have a wide range of extraction [28-30]. In addition, it has been shown that polyphenolic compounds such as saponins and inulins, which are the main constituents of Taraxacum officinale flower extracts [31-33] may be related to the formation of the inhibitory halos for the bacterial strain AB1157 when tested against fraction of the aqueous extract of the flower, since studies by Verma et al. [34] (Table 1). In the present study, it was shown that high concentrations of polyphenolic compounds (which characterize saponins and inulins) induce innumerable biological alterations, including cell membrane alterations, where significant chromosome structure damage occurs $[35,36]$.

However, according to Figure 4, it can be observed that the aqueous extract of the species Schinus terebinthifolius Raddi does not have a potentiating effect like the aqueous extract of the flower of Taraxacum officinale, but acts as an adjunct to the antibiotic, allowing it to be consumed in smaller doses when associated with the extract of Schinus terebinthifolius Raddi, remaining the same therapeutic effect. This in the era of extinction of antibiotics of the class of penicillins is of paramount importance to reduce the amount of penicillinic dispensed, generating a less waste and a greater storage.

In relation to the comparative analysis of the aqueous extract of the flower of Taraxacum officinale (Table 1), it is possible to confirm the potentiating action of this extract, having the statistical values of Tukey-Kramer, which is a test of comparative analysis of the significance of the means, in the range of $\mathrm{P}<0.001$ for the association of the extract with the antibiotics Amoxicillin and Chloramphenicol. The pharmacological effects applied to this species of the Dandelion plant described in the literature, such as the anti-inflammatory and anticancer action is seen in this method by the same way of the antibacterial effect, since the bacterium and the human has the cellular structure very similar, differentiating only by the bacterium present cell wall and the human not. By inducing the oxidative stress of the bacteria (oxidative damage), it is as if the human organism were developing a tumor, which is a form of injury. In this way, the anticancer action, mainly, can be justified by the reduction of oxidative stress, since the greater the halo, the greater the bacterial inhibition, the greater the reduction of oxidative stress, leading to the reduction of the lesion, which may be a tumor. This ability is conferred on the saponins constituent, since it induces inhibition of angiogenesis (inhibition of vascularization) of the cancer cell.

\section{Antioxidant correlation}

In the present study, the antioxidant action of the aqueous extract of the Taraxacum officinale flower was determined by the agar diffusion method, in which positive controls for the action were tin chloride $\left(\mathrm{SnCl}_{2}\right)$ and hydrogen peroxide $\left(\mathrm{H}_{2} \mathrm{O}_{2}\right)$. To know if the difference means that the drug works and is not simply a result of chance, we first established the null hypothesis of no statistical difference between the groups and the alternative hypothesis of a statistical difference. Next, we selected a statistical test to compute a test statistic, which is a standardized numerical measure of the difference between the groups. Under the null hypothesis, we expect the value of the test statistic to be small, but there is a small probability that this is large, just by chance. Once the test statistic has been calculated, we use it to calculate the p-value. The p-value is defined as the probability that a test statistic value greater than or equal to that found. Normally the cutoff value to reject the null hypothesis is 0.05 , which means that when there is no difference, such an extreme value for the test statistic is expected to be less than $5 \%$ of the time [37].

Regarding the experimental tests, it was observed that there was no antioxidant effect of the aqueous solution of both the flower extract of Taraxacum officinale (Figure 5 \& Table 1) and the extract of the leaf and branches of Schinus terebinthifolius Raddi (Figure 6) there was inhibition of the action of tin chloride $\left(\mathrm{SnCl}_{2}\right)$ on the strain Escherichia coli AB1157, whose characteristic is the sensitivity for this purpose, having the statistical value of Tukey-Kramer in the range of $\mathrm{P}>0.05$.

In the positive control, hydrogen peroxide $\left(\mathrm{H}_{2} \mathrm{O}_{2}\right)$, the aqueous extract of the flower of Taraxacum officinale decreased its oxidative action significantly, presenting the value of Tukey-Kramer in the range of $\mathrm{P}<0.001$ (Figure $5 \&$ Table 1). However, the aqueous extract of leaves and branches of Schinus terebinthifolius Raddi was not successful in the antioxidant action of the hydrogen peroxide solution $\left(\mathrm{H}_{2} \mathrm{O}_{2}\right)$, since the inhibition of its action was not significant (Figure 6), presenting the statistical value of Tukey -Kramer in the range of $\mathrm{P}<0.05$.

The concomitant use of the aqueous extract of both the Taraxacum officinale flower and the leaves and branches of Schinus terebinthifolius Raddi, plus tin chloride $\left(\mathrm{SnCl}_{2}\right)$ and hydrogen peroxide $\left(\mathrm{H}_{2} \mathrm{O}_{2}\right)$ was also observed. This evaluation obtained a significant positive result for antioxidant action characterized by the oxidative inhibition of both substances in the presence of the aqueous 
extract of the flower of Taraxacum officinale (Figure 5), in contrast, a non-significant result was obtained characterized by non-inhibition of oxidative substances in the presence of the aqueous extract of Schinus terebinthifolius Raddi.

It is a misconception that a very small value of $\mathrm{p}$ means that the difference between groups is highly relevant. As we look at the p-value alone, attention is diverted from the size of the effect. For example, $p$-value is significant, but a drug that increases urine production in $45 \mathrm{ml}$ is not clinically relevant [37]. It may be assumed that the aqueous extract of the flower of Taraxacum officinale has a greater clinical relevance than the dehydrated extract of the leaves and branches of Schinus terebinthifolius Raddi.

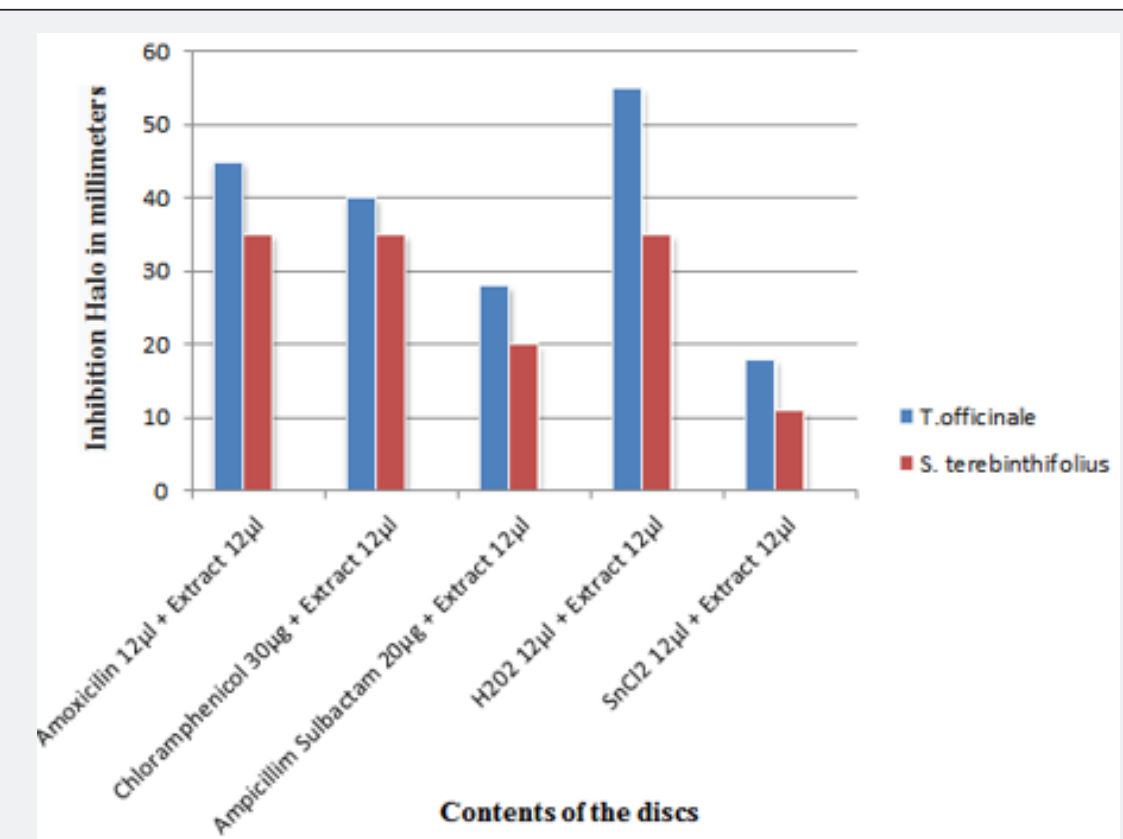

Figure 7: Comparison of averages of the halos formed by the species Taraxacum officinale and Schinus terebinthifolius Raddi on the strain of Escherichia coli AB1157.

\section{Comparative analysis}

In a comparative analysis between the therapeutic action of the aqueous extracts of the Taraxacum officinale flower and the leaves and branches of the Schinus terebinthifolius Raddi (Figure 7), bot'h studied in the Laboratory of Chemical and Biological Analysis (LAQB), it can be observed that in all the most antibiotic extract associations the aqueous extract of the flower of Taraxacum officinale showed a higher therapeutic activity than the Schinus terebinthifolius Raddi, having a mean difference in the formation of the halo of inhibition of bacterial growth between approximately 5 to $10 \mathrm{~mm}$ in diameter. The same happened with the comparative results regarding antioxidant action, where the mean difference in oxidative inhibition of tin chloride $\left(\mathrm{SnCl}_{2}\right)$ and hydrogen peroxide $\left(\mathrm{H}_{2} \mathrm{O}_{2}\right)$ ranged from 5 to $20 \mathrm{~mm}$ in diameter.

\section{Conclusion}

From the obtained results it can be suggested that possibly the aqueous extracts studied have phytochemical constituents that in association with the antibiotics, presents a certain synergism, potentializing the action of the antibiotics. Regarding the types of extracts studied, the aqueous extract of the flower of the species Taraxacum officinale, presented the formation of inhibition halos for the wild line AB1157, more significantly than the aqueous ex- tract of the leaves and branches of Schinus terebinthifolius Raddi, raising the hypothesis of the flower of Taraxacum officinale have a greater clinical relevance as to its antibacterial, anti-inflammatory and anticancer activity.

\section{Acknowledgment}

We thank the Foundation for Research Support of the State of Rio de Janeiro (FAPERJ), for the support to the research carried out in the Laboratory of Chemical and Biological Analysis (LAQB) of the Foundation State University Center of the West Zone (UEZO).

\section{References}

1. Guerra MP, Nodari RO (2007) Biodiversidade aspectos biológicos, geográficos, legais e éticos. In: Simões CMO, Schenkel EP, Gosmann G, Mello JCP, Mentz LA, Petrovick PR (Eds.), Farmacognosia: da planta ao medicamento. $6^{\text {th }}(\mathrm{edn})$, Editora da UFRGS, Porto Alegre, Brazil, pp. 1428.

2. Ribeiro KS, Guimarães ALA (2013) uso de medicamentos à base de plantas medicinais por médicos do SUS no município de Teresópolis/ RJ. Revista Agrogeoambiental, Pouso Alegre, Brazil, Edição Especial 1: 61-65.

3. Bila DM, Dezotti M (2003) Fármacos no meio ambiente. Quím Nova São Paulo 26(4): 523-530.

4. Ahmad VU, Yasmeen S, Ali Z, Khan MA, Choudhary MI, et al. (2000) Taraxacin a new guaianolide from Taraxacum wallichii. Journal of Natural Products 63: 1010-1011. 
5. Kisiel W, Barszcz B (2000) Further sesquiterpenoids and phenolics from Taraxacum officinale Fitoterapia 71: 269-273.

6. Cronquist AF (1981) Farmacognosia. 4 (edn), Lisboa: Fundação Calouste Gulbenkian 2: 1010

7. Lorenzi H, Matos FJA (2002) Plantas medicinais no Brasil: nativas e exóticas. $2^{\text {nd }}($ edn.), Instituto Plantarum, São Paulo, Brazil.

8. Velázquez, Tournier HA, Mordujovich de Buschiazzo P, Saavedra G, Schinella GR (2003) Antioxidant activity of Paraguayan plant extracts. Fitoterapia 74(1-2): 91-97.

9. Cowan MM (1999) Plant Products as Antimicrobial Agents. Clin Microbiol Rev 12(4): 564-582.

10. Teske M, Trentini AMM (1997) Compêndio de fitoterapia. $3^{\text {rd }}$ (edn.), Herbarium, Curitiba, Brazil, pp. 120-121.

11. Kissmann KG, Growth D (1992) Plantas infestantes e nocivas. São Paulo: Rev Basf Brasileira, Tomo II, p. 798.

12. Panizza S (1996) Plantas que curam (cheiro de mato) $\left(16^{\text {th }}\right.$ edn), São Paulo: IBRASA, Brazil, p. 279.

13. Alonso JR (2000) Tratado de fitomedicina, bases clínicas e farmacológicas. Rev Buenos Aires: Ediciones SRL, Brazil, p. 743.

14. Takasaki M, Konoshima T, Tokuda H, Masuda K, Arai Y, et al. (1999) Anti-carcinogenic activity of Taraxacum plant I. Biol Pharm Bull 22(6): 602-605.

15. Costa AF (1979) Farmacognosia ( $4^{\text {th }}$ edn), Lisboa: Fundação Calouste Gulbenkian 2: 1010.

16. Lorenzi H, Matos FJA (1991) Plantas daninhas do Brasil: terrestres, aquaticas, parasitas, toxicase medicinais. $\left(2^{\text {nd }}\right.$ edn), Plantarum, Nova Odessa, Brazil, p. 440.

17. Newall CA, Anderson LA, Phillipson JD (2002) Plantas Medicinas: Guia para profissional de saúde.

18. Silva CR, Monteiro MR, Caldeira De Araújo A, Bezerra RJAC (2004) Absence of mutagenic and citotoxic potentiality of senna (Cassia angustifolia Vahl.) evaluated by microbiological tests. Revista Brasileira de Farmacognosia 14: 1-2.

19. Sejas, Lilian M (2003) Avaliação da qualidade dos discos com antimicrobianos para testes de disco difusão disponíveis comercialmente no Brasil. Jornal Brasileiro de Patologia e Medicina Laboratorial 39(1): 27-35.

20. Silva EJ, Nascimento CCHC, Nascimento SF, Vasconcelos SDD De, Nogueira RI, et al. (2018) Study of the biological effects of aqueous extracts of schinus terebinthifolius raddi, on the survival fraction of mutant and wild strains of escherichia coli. Merit Rearch Journals 6(3): 89-99.

21. Alexandre RF, Bagatini F, Simões CMO (2008) Interações entre fármacos e medicamentos fitoterápicos à base de ginkgo ou ginseng. Revista Brasileira de Farmacognosia 18(1): 117-126.

22. Williamson EM (2005) Interactions between herbal and conventional medicines. Expert Opinion on Drug Safety 4(2): 355-378.
23. Fugh Berman A, Ernst E (2001) Inteer aaçvõaelisa çmãeod dicaa cmoennfitaobsailsi dcaodme deorv raesl: a rtóevriios. ã oBritish. J Clin Pharmacol 15(5): 587-595.

24. Nascimento GGF, Locatelli J, Freitas PC, Silva GL (2000) Antibacterial activity of plant extracts and phytochemicals on antibiotic-resistant bacteria. Brazilian J Microbiol 31(4): 247-256.

25. Teles DG, Costa MM (2014) Estudo da ação antimicrobiana conjunta de extratos aquosos de Tansagem (Plantago major L. Plantaginaceae) e Romã (Punica granatum L, Punicaceae) e interferência dos mesmos na ação da amoxicilina in vitro. Revista Brasileira de Plantas Medicinais 16(2) suppl 1: 323-328.

26. Martins CR, Lopes WA, Andrade JB (2013) de Solubilidade das substâncias orgânicas. Química Nova 36(8): 1248-1255.

27. Santos MRG (2015) Brief review on the medicinal uses and antimicrobial atividade do diferente partes do Schinu sterebinthifolius raddi. Int J Pharm Pharm Sci 7(12): 1-7.

28. Guerra MP, Nodari RO (2007) Biodiversidade aspectos biológicos, geográficos, legais e éticos. In: Simões CMO, Schenkel EP, Gosmann G, Mello JCP, Mentz LA, Petrovick PR (Eds.), Farmacognosia: da planta ao medicamento. ( $6^{\text {th }}$ edn), Editora da UFRGS, Porto Alegre, Brazil, pp. 1428.

29. Freires IA, etal. (2011) Atividade antifúngica de Schinus Terapinthifolius (Aroeira) sobre cepas do gênero Candida. Revista Odontológica do Brasil Central 20(52).

30. Degáspari CH, Waszczynskyj N, Santos RJ dos (2004) Atividade Antioxidante de Extrato de Fruto de Aroeira (Schinus terebinthifolius Raddi). Visão Acadêmica, Curitiba 5(2): 83-90.

31. Farag SF (2008) Compostos polifenólicos das folhas de Schinus terebinthifolius Raddi. Touro Pharm 31: 319-329.

32. El Massry KF (2009) Composições químicas e antioxidante/ antimicrobiana de várias amostras preparadas a partir de Folhas de Schinus terebinthifolius cultivadas no Egito. J Agric Food Chem 57: 5265-5270.

33. silva MM (2017) Schinus terebinthifolius: phenolic constituents and in vitro antioxidant, antiproliferative and in vivo anti-inflammatory activities. Revista Brasileira de Farmacognosia 27(4): 445-452.

34. Verma M (2013) Pharmacological evaluation of hyperin for antihyperglycemic activity and effect on lipid profile in diabetic rats. Indian J Exp Biol 51(1): 65-72.

35. Porto, Luiz Carlos Santos (2013) Evaluation of acute and subacute toxicity and mutagenic activity of the aqueous extract of pecan shells [ Carya illinoinensis (Wangenh.) K. Koch]. Food Chem Toxicol 59: 579585.

36. Giuliani C (2014) 0 flavonóide quercetina inibe a restrição da tiroide expressão gênica e função tireoidiana. Alimentos e Químicos Toxicology [sl] 66: 23-29.

37. Juliana Carvalho Ferreira, Cecilia Maria Patino (2015) 0 que realmente significa o valor-p?. J Bras Pneumol 41(5): 485-485. 


\section{Your next submission with Juniper Publishers} will reach you the below assets

- Quality Editorial service

- Swift Peer Review

- Reprints availability

- E-prints Service

- Manuscript Podcast for convenient understanding

- Global attainment for your research

- Manuscript accessibility in different formats ( Pdf, E-pub, Full Text, Audio)

- Unceasing customer service

Track the below URL for one-step submission https://juniperpublishers.com/online-submission.php 